\title{
Management international
}

International Management

Gestiòn Internacional

\section{The Dual Nature of Foreign Currency Debt and Its Impact on} Firm Performance: Evidence from French Non-Financial Firms

La double nature de la dette en devises et son impact sur la performance des entreprises : une validation empirique pour les entreprises non financières françaises

\section{La doble naturaleza de la deuda en divisa y su impacto en el rendimiento de las empresas: una validación empírica para las empresas no financieras francesas}

\section{Salma Mefteh-Wali et Marie-Josèphe Rigobert}

Volume 23, numéro 1, automne 2018

URI : https://id.erudit.org/iderudit/1060063ar

DOI : https://doi.org/10.7202/1060063ar

Aller au sommaire du numéro

Éditeur(s)

HEC Montréal

Université Paris Dauphine

ISSN

1206-1697 (imprimé)

1918-9222 (numérique)

Découvrir la revue

Citer cet article

Mefteh-Wali, S. \& Rigobert, M.-J. (2018). The Dual Nature of Foreign Currency Debt and Its Impact on Firm Performance: Evidence from French

Non-Financial Firms. Management international / International Management /

Gestiòn Internacional, 23(1), 68-77. https://doi.org/10.7202/1060063ar
Résumé de l'article

Nous étudions l'impact de la dette en devises sur la performance d'un échantillon d'entreprises non-financières françaises sur la période 2002-2012. Compte tenu de la double nature de la dette en devises, nous vérifions si cet impact résulte d'une politique de couverture ou de structure du capital. Nous constatons que la dette en devises et la dette domestique ont le même effet positif avant et négatif après la crise de 2008. Les théories de la structure du capital et de la couverture expliquent ce résultat. Pendant la crise, l'impact de la dette en devises est expliqué uniquement par la théorie de la couverture.
Tous droits réservés (C) Management international / International Management / Gestión Internacional, 2018
Ce document est protégé par la loi sur le droit d'auteur. L’utilisation des services d'Érudit (y compris la reproduction) est assujettie à sa politique d'utilisation que vous pouvez consulter en ligne.

https://apropos.erudit.org/fr/usagers/politique-dutilisation/ 


\title{
The Dual Nature of Foreign Currency Debt and Its Impact on Firm Performance: Evidence from French Non-Financial Firms
}

\section{La double nature de la dette en devises et son impact sur la performance des entreprises : Une validation empirique pour les entreprises non financières françaises}

\author{
La doble naturaleza de la deuda en divisa y su impacto en el \\ rendimiento de las empresas: una validación empírica para \\ las empresas no financieras francesas
}

\author{
SALMA MEFTEH-WALI \\ ESSCA School of Management
}

\section{ABSTRACT}

We investigate the impact of foreign currency debt on firm performance for a sample of non-financial French firms studied over the period 2002 to 2012. As foreign currency debt is both a financing and hedging instrument against foreign exchange risk, we examine whether its impact results from an optimal hedging policy or a capital structure policy. We find that foreign currency debt and domestic debt have the same positive effect before the crisis and negative impact after. The capital structure theory or the hedging theory can explain this result. During the crisis period, only corporate hedging theory explains the impact of foreign debt.

Keywords: Foreign Currency Derivatives, Foreign Currency Debt, Foreign Currency Hedging, Firm performance

\author{
MARIE-JOSÈPHE RIGOBERT \\ EDC Paris Business School
}

\section{RÉSUMÉ}

Nous étudions l'impact de la dette en devises sur la performance d'un échantillon d'entreprises non-financières françaises sur la période 2002-2012. Compte tenu de la double nature de la dette en devises, nous vérifions si cet impact résulte d'une politique de couverture ou de structure du capital. Nous constatons que la dette en devises et la dette domestique ont le même effet positif avant et négatif après la crise de 2008. Les théories de la structure du capital et de la couverture expliquent ce résultat. Pendant la crise, l'impact de la dette en devises est expliqué uniquement par la théorie de la couverture. Mots-Clés : Produits dérivés, Dette en devises, Couverture du risque de change, Performance de l'entreprise

\section{RESUMEN}

Estudiamos el impacto de la deuda en divisa sobre el desempeño de una muestra de empresas francesas no financieras durante el período 2002-2012. Dada la naturaleza dual de la deuda en divisa, verificamos si este impacto es el resultado de una política de cobertura o de estructura de capital. Observamos que la deuda en divisa y la deuda interna tienen el mismo efecto positivo antes de la crisis de 2008 y después negativo. Las teorías de estructura de capital y cobertura explican este resultado. Durante la crisis, el impacto de la deuda en divisa se explica únicamente por la teoría de la cobertura cambiaria.

Palabras Clave: Productos derivados, Deuda en divisa, Cobertura del riesgo de cambio, Desempeño de las empresas
$\mathrm{D}$ uring the past decade, a growing number of companies have chosen to borrow in foreign currencies rather than in their home currency. According to the European Central Bank, at the end of 2012, foreign currency-denominated debt represented $16 \%$ of the outstanding amount of bonds issued by non-financial corporations compared to $2 \%$ at the end of 2002 .

Firms issue foreign debt to hedge their exposure to foreign exchange risks, diversify their sources of financing, and reduce the cost of debt and transaction costs. For example, when firms have exchange rate sensitive revenues and assets, or when they want to make a direct investment in a foreign country, they can use foreign currency denominated debt in order to eliminate their exposure to exchange risk.

Firms may also issue foreign currency debt for speculative reasons, with a view to benefiting from an interest rate differential if they expect rates to deviate from uncovered interest rate parity (Keloharju and Niskanen, 2001). This may increase their exposure to fluctuations in exchange rates (Allayannis et al., 2003). By issuing foreign currency debt, firms expose themselves to an increase in the debt service burden due to the depreciation of their national currency against the debt currency. Whatever their motivations, the impact of foreign currency debt usage on firm performance is not neutral.

The rapid and growing increase in the use of foreign currency debt since 2002, calls to a better understanding of its impact on firm performance. A few empirical studies have examined this issue but their results are mixed or inconclusive. Until now, a question has not been addressed in the empirical literature.

- As foreign currency debt is both a source of financing and a hedging technique, does its impact on firm performance result from a hedging policy or from capital structure policy? 
This paper aims to provide an answer to the question raised above. To achieve this objective, we proceed as follows. First, foreign currency debt can drive performance up or down, therefore, we check its impact for French non-financial firms. We examine the link between foreign-currency debt and French non-financial firms' performance by using accounting-based corporate and market measures that capture current performance and investors' expectations about future performance respectively. Second, we split total debt into its domestic and foreign components. On the one hand, we analyze the sign of the relationship between the variables of performance and foreign currency debt, and on the other, we examine the sign of the relationship with domestic debt. We hypothesize that the effects of foreign currency debt on firm performance can be interpreted in the light of capital structure theory or optimal hedging theory if the signs are the same for both relationships. If the signs are different, they can be explained with arguments stemming exclusively from corporate hedging theory. This represents the main novelty of the paper.

This study makes several main contributions to the existing empirical literature. First, to our knowledge, it is the first empirical research to specifically target non-financial French firms ${ }^{1}$. Prior research into the effect of foreign currency debt on firm performance have focused primarily on the US, UK or Asian markets (Allayannis et al., 2003; Clark and Judge 2009) and few on the Eurozone. Vivel et al. (2013) analyzed value creation through currency hedging (with derivatives, foreign currency debt, and operational hedging) on the Spanish market over the period 20022007. Our study extends the empirical literature, which has so far focused on the impact of derivative-based hedging on firm value. The choice of French firms is well suited to the study we propose, for France is an open economy and one of the principal actors in world trade. French firms do more than 35\% of their business with non-Eurozone countries, and consequently, have significant exposure to foreign exchange risk. Moreover, France's capital markets and banking system are highly developed, such that the decision to issue foreign currency debt is driven by economic criteria rather than constraints related to a narrow capital market, transaction costs, or foreign exchange control. Although France is moving towards a capital market oriented economy, banks still have a significant role. In bank-oriented economies, agency costs and indirect bankruptcy costs are known to be lower due to the close relationship between borrowers and creditors. The French legal system is based on code of law traditions. The tax system, the insolvency code, the level of investors' protection and corporate governance practices are different from those of common-law countries. For example, most French firms are family businesses with a closely held ownership structure. For all the reasons mentioned above, the impact of foreign debt on firms' performance and its signification may be different from those of previous studies.

Second, up to now, studies have examined the effect on firm performance of either hedging strategies or financing policy. Considering the dual nature of foreign currency debt this study explains this relationship with reference to capital structure theory and optimal hedging theory.
Third, the relatively long period covered by this study makes it possible to grasp the influence of the 2008 financial crisis on the use of foreign currency debt and its consequences for firm performance. Harvey and Roper (1999) suggested that foreign currency debt contributed to the poor performance of East Asian firms during the 1997 Asian financial crisis. On the contrary, Allayannis et al. (2003) found no evidence suggesting that foreign currency debt had a significantly larger impact on a firms' financial performance than local debt during this currency crisis. The 2008 systemic and structural financial crisis might have altered the relationship between foreign debt and firm performance. This study verifies whether the valuing-effects of foreign debt and its explanation are the same before, during and after the financial crisis of 2008.

This paper is organized as follows. Section 2 presents the theoretical framework. Section 3 describes the research methodology. Section 4 presents and analyzes the empirical results. Section 5 presents the robustness check. Section 6 concludes.

\section{Theoretical framework}

Financial theories suggest that capital structure and corporate hedging impact firm performance when some frictions (i.e. taxes, transaction costs, bankruptcy costs) are introduced into the Modigliani and Miller Model (1958).

\section{Foreign CURRENCY DEBT, CAPITAL STRUCTURE, AND PERFORMANCE}

Since foreign debt is a type of debt, theories of optimal capital structure (i.e. static trade-off, pecking order signaling theory) can be applicable in explaining its impact on firm performance. According to the static trade-off theory, the tax shield resulting from the deductibility of interest leads to a positive impact of debt on firm performance. At the same time, leverage increases indirect bankruptcy and direct costs of financial distress that can deteriorate performance. Similarly, through its monitoring role, leverage alleviates the agency costs stemming from conflicts between shareholders and managers, and has a positive effect on performance, on the one hand. Yet, it increases the agency costs arising from conflicts between shareholders and bondholders, and lowers performance, on the other hand. Foreign currency debt allows firms to lessen their borrowing costs by exploiting taxes differences, arbitrage opportunities, or lower interest costs in foreign currency. However foreign currency debt increases borrowing risk and distress costs due, for example, to currency mismatch, or liquidity mismatch.

Because of information asymmetry between managers and outside investors, firms finance their projects with internal funds, then debt, and finally equity (Myers and Majluf, 1984). Among debts, they prefer domestic debt over foreign debt. The pecking order theory predicts a negative relationship between leverage and performance because more profitable firms are more likely able to generate internal funds. Allayannis et al. (2003) found roughly the same negative impact of foreign debt on performance as domestic debt. In the presence of information asymmetry, firms may use foreign debt to signal their high quality to outside

1. Ben Khediri (2010), Ben Khediri and Folus (2010), Clark and Mefteh (2010), Belghitar et al. (2013) examined the value effect of derivatives use on samples of French firms for year 2001, 2000-2002, 2004 and 2002-2005 respectively. 
investors (Ross, 1977). Since foreign currency debt must meet high standards of financial disclosure and is under increased regulatory scrutiny, it may be a costly and credible signal of a firms' creditworthiness and can increase performance.

\section{FOREIGN CURRENCY DEBT, CORPORATE HEDGING AND FIRM PERFORMANCE}

Foreign currency debt is a natural hedging strategy and as such, can have a mixed impact on firm performance. The theories suggest that corporate hedging can increase firm performance by reducing volatility and expected tax liability in presence of convex tax schedule (Smith and Stulz, 1985), by mitigating underinvestment costs stemming from agency costs of debt or costly recourse to external financing (Bessembinder, 1991; Froot et al., 1993), and by lowering financial distress costs. Clark and Judge (2009), Bartram et al. (2009), and, Vivel et al. (2013) showed that foreign currency use increases firm performance.

However, foreign currency debt can increase the exposure to exchange rate fluctuations and thus, requires hedging with derivatives. If the currency derivatives program is ill-structured, it can impact firm value negatively. Allayannis et al. (2003) found that foreign currency debt hedged with derivatives deteriorated Asian firms' performance. Firms can also use foreign currency debt for speculative purposes, willfully increase their exposure to exchange rate fluctuations, and accept a fall in performance.

\section{Research methodology}

This section describes the sample and presents the model used to analyze the relationship between a firm's performance and its foreign currency debt.

\section{THE SAMPLE}

The initial sample comprised the largest 250 French non-financial firms listed on Euronext that form the CAC All-Tradable index (ex SBF 250) and observed over the period 2002 to 2012. We excluded firms from the financial industry because of the nature of their activity (hedging and trading) and their specific financing characteristics. We also excluded public firms because they may have different incentives associated with foreign currency debt usage. We removed firms that did not disclose any information on their foreign currency debt policy or their hedging strategy, and firms with missing accounting and financial data. A firm was definitively included in the sample if it stated, in its annual report, that it had foreign currency exposure and the financial data could be found in the Datastream and Thomson One Banker databases. Specifically, the final sample consists of a balanced panel of 115 firms each year or a total of 1,265 firm/year observations. Among these 115 companies, there are 7 subsidiaries of European companies and 2 subsidiaries of American companies. All firms are exposed to currency risk but only some of them use foreign currency debt.

We obtain the data from various sources. Firms' foreign currency debt and risk hedging policies data were collected manually from the annual reports. Stock market, accounting, and financial data were extracted from the Datastream and Thomson One Banker databases.

\section{Methodology}

We estimate a regression with performance measures as dependent variables and debt types (foreign currency debt and domestic debt) as independent variables to investigate the effect of foreign currency debt on performance variables. We also include other independent variables to control for some factors that other studies have assumed to affect performance. The analysis model is as follows:

Firm Performance $=f$ (foreign currency debt, domestic currency debt, control variables).

\section{VARIABLES}

\section{Firm performance}

We capture firm performance using Return on Assets (ROA), Return on equity $(R O E)$ and Tobin's $Q$. ROA is defined as earnings before interest and taxes, divided by the book value of assets. ROE is defined as the ratio of net income to the book value of equities. Tobin's $Q$ is defined as the market value of equities plus the book value of debt to the book value of assets ${ }^{2}$. Since the distribution of Tobin's $Q$ in our sample is skewed, we use the natural logarithm of Tobin's $\mathrm{Q}$, denoted LNTQ.

\section{Foreign currency debt and domestic currency debt}

Table 1 shows the distribution of the percentage of foreign currency debt over the period.

French firms used foreign currency debt in approximately the same proportion before and during the crisis (around 16\%).

\begin{tabular}{|l|c|c|c|c|}
\hline \multicolumn{5}{|c|}{$\begin{array}{c}\text { TABLE 1 } \\
\text { Description of foreign currency debt }\end{array}$} \\
\hline \multicolumn{1}{|c|}{ This table describes the percentage of foreign currency debt. There are 1,265 firm/year observations. } \\
\hline & Pre-crisis period [2002-2006] & Crisis [2007-2009] & Post-crisis [2010-2012] & Entire period [2002-2012] \\
\hline Mean & 0.1615 & 0.1598 & 0.1974 & 0.1711 \\
\hline Std. Dev. & 0.2247 & 0.2487 & 0.2677 & 0.2450 \\
\hline Min & 0 & 0 & 0 & 0 \\
\hline Max & 1 & 1 & 1 & 1 \\
\hline
\end{tabular}

2. In the literature, different measures of Tobin's Q are proposed (Perfect and Wiles, 1994; Lewellen and Badrinath, 1997; Allayannis and Weston, 2001). The results are roughly the same regardless of the measure used. 
In the post-crisis period, this percentage rose to $19 \%$ of total debt. During the crisis period, the Euro bond market dried up, and this drove several large French firms to seek financing on the US dollar or Sterling bond markets. From 2010, French firms reduced their dependence on banks and diversified their sources of financing, particularly through bond issues in foreign currencies (e.g. US dollars, Japanese yen, Great British pounds, and Chinese yuan), private placements on the US market (USPP), or private placements on the German market (Schuldschein) in US dollars, Great British pounds, or Swiss francs.

We break leverage into a foreign currency component (FOREIGN LEV) and a domestic component (DOMESTIC $L E V)$ to capture the specific impact of foreign currency debt as a currency-hedging instrument.

FOREIGN LEV is the ratio of long-term foreign currency debt (nominal value of foreign currency debt) to total assets. Based on arguments from capital structure theory and corporate hedging theory, the relationship between FOREIGN LEV and performance variables could be any sign.

DOMESTIC LEV is the ratio of long-term local currency debt (nominal value of domestic debt) to total assets. Based on arguments from the capital structure theory, we have no prior expectation about the sign of the relationship between $D O M E S T I C L E V$ and firm performance.

\section{CONTROL VARIABLES:}

The model includes several control variables known to impact firm performance, such as size, hedging with derivatives, investment opportunities, liquidity, Dividend payment and Geographic diversification

Size: The effect of size on firm performance is ambiguous (Peltzman, 1977; Mueller, 1987). Large firms are usually more diversified, have more human and financial resources, and benefit from economies of scale, which are likely to increase their performance. On the other hand, large firms are more likely to face agency conflicts. As they are less subject to information asymmetry, they are more prone to issue debt, especially foreign currency-denominated debt, which affects their performance. Allayannis and Weston (2001) found that larger firms have lower performance while Jin and Jorion (2006) found the contrary. A firm's size (SIZE) is approximated by the logarithm of the book value of total assets. Given the arguments put forward in the previous literature, we have no prior expectations about the sign of the relationship between the size variable and the performance variables.

Hedging with derivatives: Foreign currency debt and foreign currency derivatives use are either complementary (Elliott et al. 2003; Bartram et al., 2009) or substitutable strategies (Allayannis and Ofek, 2001; Aabo, 2006 and Mefteh-Wali and Rigobert, 2013). Foreign currency derivatives usage (DERIV) is measured by the fiscal year-end total notional value of derivatives deflated by total assets. The relationship between DERIV and performance variables can be any sign.

Investment opportunities: The market value of a firm incorporates the present value of its future investment opportunities (Myers, 1977). This means that the higher are the investment opportunities, the greater is the value. However, market imperfections (transaction costs and information asymmetry) increase the cost of external financing and prevent firms from siezing certain opportunities. We use the ratio of capital expenditure to the firm's market value (CAPEX) to proxy for investment opportunities. CAPEX is expected to be positively related to the performance variables.

Liquidity: Firms that are not cash constrained can honour payments, suggesting a positive relationship between liquidity and performance. However, excessive free cash flow can encourage managers to invest in projects with negative present value (Jensen, 1986). Thus, the expected relationship is negative. As proxy for liquidity, we use the quick ratio (QUICK), defined as the total of available cash accounts and marketable securities to short-term liabilities. The sign of the relationship between Quick and the performance variables is undetermined.

Dividend payment: In the literature, the payment of dividends is interpreted as a firm's ability to access financial markets. Firms that have restricted internal resources and limited access to financial markets take on only those projects with the highest net present value and forego others that could be value enhancing. Jin and Jorion (2006) hypothesized a negative relationship between dividend yield (DIV) and performance while Allayannis and Weston (2001) expected a positive one. Dividends can also be viewed as a costly positive signal from management, which should imply a positive coefficient of the dividends variables (Bhattacharya, 1979). Thus, the sign of the relationship between DIV that is the ratio of dividend per share to share price and the performance variables is not defined.

Geographic diversification: Some theories suggested that firm performance was positively correlated with geographic diversification (Coase, 1937; Dunning, 1973). Some others suggested a negative correlation considering that geographic diversification is a consequence of agency problems. Allayannis and Weston (2001) found that geographic diversification is positively related to firm value. We use the ratio of foreign sales to total sales (FSTS) as proxy of geographic diversification and expect the sign of FSTS to be positive.

The Appendix summarises the variables discussed in the text.

Table 2 reports descriptive statistic of the variables. The firms have average Tobin's Q of 1.7120 , average ROA of $3.82 \%$ and average $R O E$ of $6.42 \%$. Foreign currency debt mean is $4.3 \%$ and the maximum is $34.9 \%$. DOMESTIC LEV represents $13 \%$ on average. Some firms have no debt regardless the type. The average notional value of the portfolio of derivatives is $8.9 \%$ of total assets. Some firms in the sample do not use foreign exchange derivatives. Average QUICK ratio is 1.013, average DIV is $1.96 \%$ and average FSTS is $51.42 \%$.

Table 3 presents the correlation matrix between the variables. Firm value $(L N T Q)$ is negatively and significantly correlated with firm SIZE, DOMESTIC LEV, and the firm's dividend distribution policy, DIV. LNTQ is positively related to FOREIGN $L E V, Q U I C K$, and CAPEX, respectively.

$R O A$ and $R O E$ are negatively and significantly correlated with DOMESTIC LEV and positively and significantly linked to SIZE, DIV, CAPEX, and QUICK. 
This table presents the summary statistics of the variables. The sample consists of large non-financial firms observed in the period 2002 to 2012 with a total of $1,265 \mathrm{firm} /$ year observations. $R O A$ is the earnings before interest and taxes on the book value of assets. ROE is the net income divided by the book value of equities. Tobin's $Q$ is equal to the market capitalization plus the book value of debt divided by the book value of total assets. LNTQ is the natural logarithm of Tobin's Q. FOREIGN LEV is the ratio of long-term debt denominated in foreign currency to total assets. DOMESTIC LEV is the ratio of long-term debt in local currency to total assets. SIZE is the natural logarithm of the firm's total assets. DERIV is defined as the notional amount of foreign currency derivatives divided by total assets. CAPEX is the ratio of total capital expenditure to total assets. QUICK is the ratio of cash accounts and marketable securities to short-term liabilities. $D I V$ is the dividend per share divided by the share price. FSTS is the ratio of foreign sales to total sales.

\begin{tabular}{|l|c|c|c|c|}
\hline Variable & Min & Mean & Median & Max \\
\hline ROA & -0.1697 & 0.0381 & 0.0416 & 0.1732 \\
\hline ROE & -0.3154 & 0.0642 & 0.0599 & 0.3472 \\
\hline Tobin's Q & 0.3195 & 1.7120 & 1.0957 & 3.4186 \\
\hline LNTQ & -1.1411 & 0.5376 & 0.0914 & 1.2292 \\
\hline FOREIGN LEV & 0.0000 & 0.0431 & 0.0115 & 0.3491 \\
\hline DOMESTIC LEV & 0.0000 & 0.1302 & 0.1466 & 0.1351 \\
\hline SIZE & 16.3561 & 20.5842 & 20.3925 & 25.1559 \\
\hline DERIV & 0.0000 & 0.0893 & 0.0099 & 0.9814 \\
\hline CAPEX & 0.3047 & 4.4554 & 3.5784 & 20.2705 \\
\hline QUICK & 0.3153 & 1.0137 & 0.8994 & 2.9377 \\
\hline DIV & 0.0000 & 1.9664 & 1.7668 & 7.6461 \\
\hline FSTS & 0.0000 & 0.5142 & 0.5234 & 0.9886 \\
\hline
\end{tabular}

\section{THE ANALYSIS MODEL}

The model we estimate is as follows:

$$
\begin{aligned}
& \text { Perf }_{i t}=b_{0}+b_{1} \text { DOMESTIC LEV } \\
& +b_{3 t}+b_{2} \text { FORERIV } V_{i t}+b_{4} \text { SIZE } E_{i t}+b_{5} \text { CAPEX } X_{i t}+b_{6} \text { QUICK }_{i t}+ \\
& b_{7} D I V_{i t}+b_{8} \text { FSTS } \\
& \text { it }
\end{aligned}
$$

We examine whether the financial crisis of 2008 modifies the relationship between foreign currency debt and the performance of non-financial firms. To control for the effect of financial crisis, we created three dummy variables: Precrisis, Crisis, and Postcrisis. The variable Precrisis equals 1 if the observation concerns the time period 2002 to 2006, and 0 otherwise. Crisis takes a value of 1 if the observation is for the years 2007 to 2009, and 0 otherwise. Postcrisis equals 1 for the years 2010 to 2012 and 0 otherwise. Since derivatives and foreign debt are either complements or substitutes for currency risk hedging, we control the impact of the financial crisis using the same dummy variables.

Finally, our model is as follows:

$$
\begin{aligned}
& \operatorname{Perf}_{i t}=b_{0}+b_{1} \text { DOMESTIC LEV } V_{i t} \times \text { Precrisis }+ \\
& b_{2} \text { DOMESTIC LEV } V_{i t} \times \text { Crisis }+b_{3} \text { DOMESTIC LEV } V_{i t} \times \\
& \text { PostCrisis }+b_{4} \text { FOREIGN LEV } V_{i t} \times \text { Precrisis }+ \\
& b_{5} \text { FOREIGN LEV } V_{i t} \times \text { Crisis }+b_{6} \text { FOREIGN LEV } V_{i t} \times \\
& \text { PostCrisis }+b_{7} \text { DERIV } V_{i t} \times \text { Precrisis }+b_{8} \text { DERIV } V_{i t} \times \\
& \text { Crisis }+b_{9} \text { DERIV } V_{i t} \times \text { PostCrisis }+b_{10} S I Z E_{i t}+ \\
& b_{11} \text { CAPEX }_{i t}+b_{12} \text { QUICK }_{i t}+b_{13} \text { DIV }_{i t}+b_{14} \text { FSTS }_{i t}+\varepsilon_{i t}
\end{aligned}
$$

Where $b_{1}\left(b_{4}\right)$ measures the effect of domestic debt (foreign debt) use on firm performance on the Pre-crisis period from 2002 to 2006;

$b_{2}\left(b_{5}\right)$ measures the effect of domestic (foreign) debt use on firm performance on the Crisis period from 2007 to 2009;

$b_{3}\left(b_{6}\right)$ measures the effect of domestic (foreign) debt use on firm performance on the Post-crisis period from 2010 to 2012; $b_{7}$ measures the effect of derivatives use on firm performance on the Pre-crisis period;

$b_{8}$ measures the effect of derivatives use on firm performance on the Crisis period;

and $b_{9}$ measures the effect of derivatives use on firm performance on the Post-crisis period.

To estimate the model (2), we first use a pooled ordinary least squares (OLS) regression. However, as the firms are observed over more than one time period, we also use models specific to panel data. We use a random individual-effect model and a fixed-effect model to address unobservable individual variables. The first model assumes that there is no correlation between the model's explanatory variables and unobservable individual variables, and the second one accommodates such a correlation. Then, we conduct a Hausman (1978) specification test, which leads to the conclusion that the fixed-effect model is the most suitable model for our sample.

\section{Results and Discussion}

\section{UNIVARIATE ANALYSIS}

To assess the effect of foreign currency debt on a firms' value, we compare the mean value of performance variables (Tobin's $Q, R O A$, and $R O E$ ) for foreign currency debt users and for non-users. The results of this non-parametric test (t-test), reported in Table 4, show that on average, foreign debt users have higher Tobin's $Q$ and $R O A$. This difference in the mean Tobin's Q is statistically significant at the $5 \%$ level. On the contrary, they have on average a lower $R O E$ but the difference is not statistically significant.

\section{Multivariate analysis}

Table 5 reports the results of the pooled OLS and the fixedeffect regressions. 


\section{TABLE 3}

Correlation matrix

This table portrays Pearson correlation coefficients between variables. ROA is the earnings before interest and taxes on the book value of assets. ROE is the net income divided by the book value of equities. Tobin's $Q$ is equal to the market capitalization plus the book value of debt divided by the book value of total assets. LNTQ is the natural logarithm of Tobin's Q. FOREIGN LEV is the ratio of long-term debt denominated in foreign currency to total assets. DOMESTIC LEV is the ratio of long-term debt in local currency to total assets. SIZE is the natural logarithm of the firm's total assets. DERIV is defined as the notional amount of foreign currency derivatives divided by total assets. CAPEX is the ratio of total capital expenditure to total assets. QUICK is the ratio of cash accounts and marketable securities to short-term liabilities. DIV is the dividend per share divided by the share price. FSTS is the ratio of foreign sales to total sales. All variables are winsorized at the 1st and 99 th percentiles. The a, b, and c indicate significance at the 1, 5, and 10\% levels, respectively.

\begin{tabular}{|c|c|c|c|c|c|c|c|c|c|c|c|}
\hline & $R O A$ & ROE & LNTQ & $\begin{array}{c}\text { FOREIGN } \\
\text { LEV }\end{array}$ & $\begin{array}{c}\text { DOMESTIC } \\
\text { LEV }\end{array}$ & DERIV & SIZE & DIV & CAPEX & QUICK & FSTS \\
\hline$R O A$ & 1.0000 & & & & & & & & & & \\
\hline$R O E$ & $0.7012^{\mathrm{a}}$ & 1.0000 & & & & & & & & & \\
\hline$\angle N T Q$ & $0.2853^{a}$ & $0.2650^{a}$ & 1.0000 & & & & & & & & \\
\hline FOREIGN LEV & 0.0146 & -0.0100 & 0.0233 & 1.0000 & & & & & & & \\
\hline DOMESTIC LEV & $-0.1220^{a}$ & $-0.1046^{a}$ & $-0.0851^{a}$ & $-0.1305^{a}$ & 1.0000 & & & & & & \\
\hline$D E R / V$ & 0.0049 & 0.0092 & -0.0117 & $0.2207^{a}$ & $-0.0820^{a}$ & 1.0000 & & & & & \\
\hline SIZE & $0.0622^{b}$ & $0.0902^{\mathrm{a}}$ & $-0.1816^{a}$ & $0.1624^{\mathrm{a}}$ & $0.2361^{a}$ & $0.1540^{a}$ & 1.0000 & & & & \\
\hline DIV & $0.3188^{a}$ & $0.2358^{a}$ & $-0.1024^{a}$ & 0.0285 & 0.0024 & 0.0166 & $0.3044^{a}$ & 1.0000 & & & \\
\hline CAPEX & $0.1611^{\mathrm{a}}$ & $0.1352^{a}$ & $0.0520^{c}$ & $0.1418^{a}$ & $0.0894^{b}$ & 0.0434 & $0.1281^{a}$ & $0.1222^{\mathrm{a}}$ & 1.0000 & & \\
\hline QUICK & $0.1278^{a}$ & $0.0606^{b}$ & $0.3947^{a}$ & $-0.0792^{a}$ & $-0.2510^{a}$ & -0.0147 & $-0.3409^{a}$ & -0.0324 & $-0.1281^{a}$ & 1.0000 & \\
\hline FSTS & $0.0520^{\circ}$ & -0.0105 & 0.0427 & $0.1788^{a}$ & -0.0289 & $0.1549^{a}$ & $0.2895^{a}$ & 0.0174 & 0.0051 & 0.0333 & 1.0000 \\
\hline
\end{tabular}

\section{TABLE 4}

Mean comparison for performance variables

This table reports the estimation of model (2). The sample consists of large non-financial firms observed in the period 2002 to 2012 with a total of 1,265 firm/year observations. ROA is the earnings before interest and taxes on the book value of assets. ROE is the net income divided by the book value of equities. Tobin's $Q$ is equal to the market capitalization plus the book value of debt divided by the book value of total assets. LNTQ is the natural logarithm of Tobin's Q. FOREIGN LEV is the ratio of long-term debt denominated in foreign currency to total assets. DOMESTIC LEV is the ratio of long-term debt in local currency to total assets. DERIV is defined as the notional amount of foreign currency derivatives divided by total assets. SIZE is the natural logarithm of the firm's total assets. DIV is the dividend per share divided by the share price. CAPEX is the ratio of total capital expenditure to total assets. QUICK is the ratio of cash accounts and marketable securities to short-term liabilities. FSTS is the ratio of foreign sales to total sales. Pre-crisis equals 1 if the observation concerns the time period 2002 to 2006, and 0 otherwise. Crisis takes a value of 1 if the observation is for the years 2007 to 2009 , and 0 otherwise. Post-crisis equals 1 for the years 2010 to 2012 and 0 otherwise. All continuous variables are winsorized at the 1 st and 99 th percentiles. a, b, and c indicate significance at the 1,5, and $10 \%$ levels, respectively.

\begin{tabular}{|l|c|c|c|}
\hline & With foreign currency debt & Without foreign currency debt & t-statistic \\
\hline Tobin's $Q$ & 1.1009 & 1.0601 & $2.0954^{\mathrm{b}}$ \\
\hline ROE & 0.0638 & 0.0651 & 0.1753 \\
\hline ROA & 0.0392 & 0.0350 & $-2.2031^{\mathrm{b}}$ \\
\hline
\end{tabular}

\section{THE EFFECT OF FOREIGN CURRENCY DEBT ON FIRM PERFORMANCE}

We find a positive and significant relationship between foreign currency debt and each performance proxy during the pre-crisis, and a negative one in the post-crisis. This indicates that foreign debt enhances firm performance in pre-crisis. This result is consistent with the documented evidence in Clark and Judge (2009) and Vivel (2013). In the post-crisis period, the relationship is negative and significant whatever the proxy of firm performance used. During the crisis period, we find a positive impact of foreign debt only with LNTQ. These seemingly contradictory results are not surprising since ROA and ROE show current performance while LNTQ capture ex-ante performance. Besides, domestic debt has the same negative impact on ROA and ROE. This indicates that leverage decreases ex-post performance.
Several of the control variables are significant. Small firms, firms with foreign sales and those financially constrained are associated with higher LNTQ. On the contrary, firms that use derivatives and borrow in local currency have a lower performance for almost all of the periods. Large firms that benefit from economies of scale are associated with higher ROA and ROE.

\section{THE PERFORMANCE OF FOREIGN CURRENCY DEBT USE: A FINANCING LOGIC VERSUS HEDGING LOGIC.}

We compare the sign of the relationship between the variables of performance and foreign currency debt, and domestic debt respectively.

Foreign currency debt and domestic currency debt similarly impact firm value (LNTQ), positively in the pre-crisis period, 
and negatively in the post-crisis period. Therefore, the value effect of foreign currency debt can result both from a financing and a corporate hedging logic. The positive value-effect of foreign currency debt is consistent with some predictions of the capital structure theory. Specifically, the signaling theory can explain this positive effect. French firms that have accepted increased scrutiny, signal their high quality to outside investors who, in turn, reward them with a higher value. Another explanation can be found in the static trade off-and the agency theories. As Harvey et al (2004) suggests, foreign currency debt plays a monitoring role and reduces agency costs because firms that use foreign currency debt must meet high standards of financial disclosure. At the same time, French firms may use foreign debt as a naturel hedge against their currency risk. This corroborates evidence in Mefteh-Wali and Rigobert (2013) who showed that French firms studied over the period 2005 to 2010 used foreign currency debt for hedging purposes.

\section{TABLE 5}

Foreign currency debt and firm performance

This table reports the estimation of model (2). The sample consists of large non-financial firms observed in the period 2002 to 2012 with a total of 1,265 firm/year observations. ROA is the earnings before interest and taxes on the book value of assets. ROE is the net income divided by the book value of equities. Tobin's $Q$ is equal to the market capitalization plus the book value of debt divided by the book value of total assets. LNTQ is the natural logarithm of Tobin's Q. FOREIGN LEV is the ratio of long-term debt denominated in foreign currency to total assets. DOMESTIC LEV is the ratio of long-term debt in local currency to total assets. DERIV is defined as the notional amount of foreign currency derivatives divided by total assets. SIZE is the natural logarithm of the firm's total assets. DIV is the dividend per share divided by the share price. CAPEX is the ratio of total capital expenditure to total assets. QUICK is the ratio of cash accounts and marketable securities to short-term liabilities. FSTS is the ratio of foreign sales to total sales. Pre-crisis equals 1 if the observation concerns the time period 2002 to 2006, and 0 otherwise. Crisis takes a value of 1 if the observation is for the years 2007 to 2009 , and 0 otherwise. Post-crisis equals 1 for the years 2010 to 2012 and 0 otherwise. All continuous variables are winsorized at the 1st and 99 th percentiles. a, b, and c indicate significance at the 1, 5, and $10 \%$ levels, respectively.

\begin{tabular}{|c|c|c|c|c|c|c|}
\hline \multirow[t]{2}{*}{ Dependent Variable } & \multicolumn{2}{|c|}{ LNTQ } & \multicolumn{2}{|c|}{ ROE } & \multicolumn{2}{|r|}{ ROA } \\
\hline & Pooled OLS & Fixed effet model & Pooled OLS & Fixed effet model & Pooled OLS & Fixed effet model \\
\hline Constant & $\begin{array}{l}-0.452^{b} \\
(0.0120)\end{array}$ & $\begin{array}{l}0.8257^{\mathrm{b}} \\
(0.000)\end{array}$ & $\begin{array}{l}0.8450 \\
(0.358)\end{array}$ & $\begin{array}{l}-0.1256 \\
(0.858)\end{array}$ & $\begin{array}{c}-0.3653 \\
(0.404)\end{array}$ & $\begin{array}{c}-0.1129^{a} \\
(0.020)\end{array}$ \\
\hline DOMESTIC LEV $\times$ Pre-crisis & $\begin{array}{c}0.1733^{a} \\
(0.0000) \\
\end{array}$ & $\begin{array}{c}0.0735^{a} \\
(0.0000)\end{array}$ & $\begin{array}{c}-0.5737 \\
(0.103) \\
\end{array}$ & $\begin{array}{c}-0.3401 \\
(0.112) \\
\end{array}$ & $\begin{array}{l}-0.1911^{\mathrm{b}} \\
(0.0565) \\
\end{array}$ & $\begin{array}{l}-0.1075^{b} \\
(0.0302) \\
\end{array}$ \\
\hline DOMESTIC LEV $\times$ Crisis & $\begin{array}{l}-0.2232^{\mathrm{b}} \\
(0.0178)\end{array}$ & $\begin{array}{l}-0.3458^{c} \\
(0.0521)\end{array}$ & $\begin{array}{c}-0.12548^{b} \\
(0.029)\end{array}$ & $\begin{array}{l}-0.0856^{c} \\
(0.1000)\end{array}$ & $\begin{array}{l}-0.0182 \\
(0.5340)\end{array}$ & $\begin{array}{l}-0.0236^{a} \\
(0.0062)\end{array}$ \\
\hline DOMESTIC LEV x Post-crisis & $\begin{array}{c}-0.7714^{a} \\
(0.001) \\
\end{array}$ & $\begin{array}{c}-0.2770^{c} \\
(0.062) \\
\end{array}$ & $\begin{array}{l}-0.2241^{a} \\
(0.0000)\end{array}$ & $\begin{array}{c}-0.2871^{b} \\
(0.430)\end{array}$ & $\begin{array}{l}-0.0592^{c} \\
(0.0990) \\
\end{array}$ & $\begin{array}{l}-0.0771^{a} \\
(0.0010) \\
\end{array}$ \\
\hline FOREIGN LEV x Pre-crisis & $\begin{array}{l}0.5273^{a} \\
(0.0000)\end{array}$ & $\begin{array}{l}0.31650^{\mathrm{a}} \\
(0.0000)\end{array}$ & $\begin{array}{c}0.1753^{\mathrm{b}} \\
(0.0251)\end{array}$ & $\begin{array}{c}0.1988^{\mathrm{b}} \\
(0.0260)\end{array}$ & $\begin{array}{l}0.0971^{c} \\
(0.0631) \\
\end{array}$ & $\begin{array}{l}0.0702^{\mathrm{b}} \\
(0.0390) \\
\end{array}$ \\
\hline FOREIGN LEV $\times$ Crisis & $\begin{array}{l}0.1731^{c} \\
(0.0520) \\
\end{array}$ & $\begin{array}{l}0.01547^{c} \\
(0.0681)\end{array}$ & $\begin{array}{c}-0.1534^{b} \\
(0.039) \\
\end{array}$ & $\begin{array}{l}-0.2630^{c} \\
(0.0511) \\
\end{array}$ & $\begin{array}{l}-0.0321^{\mathrm{b}} \\
(0.0192) \\
\end{array}$ & $\begin{array}{l}-0.0814^{b} \\
(0.0230) \\
\end{array}$ \\
\hline FOREIGN LEV $\times$ Post-crisis & $\begin{array}{l}-0.2421^{c} \\
(0.0880) \\
\end{array}$ & $\begin{array}{c}-0.5573^{c} \\
(0.058) \\
\end{array}$ & $\begin{array}{l}-0.1215^{c} \\
(0.0690) \\
\end{array}$ & $\begin{array}{c}-0.1880^{\mathrm{b}} \\
(0.036)\end{array}$ & $\begin{array}{c}-0.0569 \\
(0.231) \\
\end{array}$ & $\begin{array}{l}-0.0705^{c} \\
(0.0230) \\
\end{array}$ \\
\hline DERIV $\times$ Pre-crisis & $\begin{array}{l}-0.4117^{a} \\
(0.0033)\end{array}$ & $\begin{array}{l}-0.3415^{a} \\
(0.0031)\end{array}$ & $\begin{array}{l}-0.1051 \\
(0.153) \\
\end{array}$ & $\begin{array}{l}-0.0496 \\
(0.1520) \\
\end{array}$ & $\begin{array}{l}-0.1620 \\
(0.431)\end{array}$ & $\begin{array}{l}-0.0231 \\
(0.2921) \\
\end{array}$ \\
\hline DERIV $\times$ Crisis & $\begin{array}{l}-0.0871 \\
(0.4324)\end{array}$ & $\begin{array}{l}-.16672^{\mathrm{b}} \\
(0.0318) \\
\end{array}$ & $\begin{array}{l}-0.0160 \\
(0.6120) \\
\end{array}$ & $\begin{array}{c}-0.0238 \\
(0.523) \\
\end{array}$ & $\begin{array}{c}-0.0126 \\
(0.8400)\end{array}$ & $\begin{array}{l}-0.0425 \\
(0.8231)\end{array}$ \\
\hline DERIV $\times$ Post-crisis & $\begin{array}{l}-0.1625 \\
(0.1460) \\
\end{array}$ & $\begin{array}{r}-0.0747 \\
(0.496) \\
\end{array}$ & $\begin{array}{c}-0.0328 \\
(0.415) \\
\end{array}$ & $\begin{array}{l}0.03752 \\
(0.289) \\
\end{array}$ & $\begin{array}{c}-0.0271 \\
(0.752) \\
\end{array}$ & $\begin{array}{l}-0.0671 \\
(0.7123) \\
\end{array}$ \\
\hline SIZE & $\begin{array}{l}-0.0089 \\
(0.1580) \\
\end{array}$ & $\begin{array}{l}-0.0862^{\mathrm{a}} \\
(0.0000)\end{array}$ & $\begin{array}{l}0.0828 \\
(0.143) \\
\end{array}$ & $\begin{array}{c}0.0313^{c} \\
(0.0932) \\
\end{array}$ & $\begin{array}{l}0.0093 \\
(0.918) \\
\end{array}$ & $\begin{array}{l}0.0521^{\mathrm{b}} \\
(0.0210)\end{array}$ \\
\hline DIV & $\begin{array}{l}-0.0168^{b} \\
(0.0158)\end{array}$ & $\begin{array}{l}-.05444^{\mathrm{a}} \\
(0.0000)\end{array}$ & $\begin{array}{c}0.1141^{\mathrm{a}} \\
(0.0000)\end{array}$ & $\begin{array}{c}0.03171 \\
(0.6820) \\
\end{array}$ & $\begin{array}{l}0.8660^{\mathrm{a}} \\
(0.000)\end{array}$ & $\begin{array}{c}0.0621^{a} \\
(0.0000)\end{array}$ \\
\hline CAPEX & $\begin{array}{l}0.0132 \\
(0.101) \\
\end{array}$ & $\begin{array}{c}0.0047 \\
(0.2040)\end{array}$ & $\begin{array}{c}0.0321^{a} \\
(0.0010)\end{array}$ & $\begin{array}{c}0.0241^{\mathrm{a}} \\
(0.0090)\end{array}$ & $\begin{array}{c}0.2545^{a} \\
(0.0000)\end{array}$ & $\begin{array}{c}0.0312^{\mathrm{a}} \\
(0.0000)\end{array}$ \\
\hline QUICK & $\begin{array}{l}0.4271^{\mathrm{a}} \\
(0.000)\end{array}$ & $\begin{array}{c}0.2992^{\mathrm{a}} \\
(0.0000)\end{array}$ & $\begin{array}{c}0.0252^{\mathrm{a}} \\
(0.0287) \\
\end{array}$ & $\begin{array}{c}0.0396^{\mathrm{a}} \\
(0.0000)\end{array}$ & $\begin{array}{c}0.0261^{\mathrm{a}} \\
(0.0000)\end{array}$ & $\begin{array}{c}0.3021^{\mathrm{a}} \\
(0.0000) \\
\end{array}$ \\
\hline FSTS & $\begin{array}{l}0.1254^{b} \\
(0.025)\end{array}$ & $\begin{array}{l}0.1347^{c} \\
(0.057) \\
\end{array}$ & $\begin{array}{c}-0.3494 \\
(0.328) \\
\end{array}$ & $\begin{array}{c}-0.4018 \\
(0.847) \\
\end{array}$ & $\begin{array}{l}0.4863 \\
(0.462) \\
\end{array}$ & $\begin{array}{l}-0.1447 \\
(0.882) \\
\end{array}$ \\
\hline Time effect & YES & YES & YES & YES & YES & YES \\
\hline Firm effect & NO & YES & NO & YES & NO & Yes \\
\hline No. observations & 1,265 & 1,265 & 0.0000 & 1,265 & 1,265 & 1,265 \\
\hline Prob $>F$ & 0.0000 & 0.0000 & 0.0000 & 0.0000 & 0.0000 & 0.0000 \\
\hline Adjusted R-squared & 0.2968 & 0.3579 & 0.1232 & 0.0904 & 0.1892 & 0.1228 \\
\hline
\end{tabular}


The negative effect of foreign debt in the post crisis period is in line with the predictions of the pecking order theory. Investors consider that more profitable firms have less need to use external financing. Foreign currency debt has a larger negative impact on French firms' performance than domestic debt.

During the crisis, the coefficient of foreign currency debt in the LNTQ regression is positive and significant while the coefficient of domestic debt is negative. Consequently, only arguments from corporate hedging theory (reduction of cash flows volatility and of underinvestment costs) can justify the positive effect of foreign debt on French firms' performance. This result differs from Allayannis et al. (2003) who found that foreign currency debt had a negative impact on East Asia firms during the 1997 Asian financial Crisis.

Arguments of static-trade off theory support the negative impact of domestic debt on firm performance. The tax shield benefits resulting from the deductibility of interest have been cancelled by investors' personal taxation (Myers 1977). In France, taxes on dividends and capital gains have always been lower than the taxes on debt income. Likewise, during the crisis, high leverage increases the likelihood of financial distress and reduces profitability.

The relationship between the DERIV and LNTQ variables is negative regardless of the period. It is significant for the precrisis and crisis periods. This result contrasts with most previous studies including Clark and Mefteh (2010) and Belghitar et al. (2013) for French firms'value. However, this result corroborates the findings of Ben Khediri (2010) and Ben Khediri and Folus (2010) who explain the negative value-effect of derivatives use for French firms by ownership structure (concentrated ownership, strong presence of founding family) and country-level corporate governance. Interestingly, foreign currency debt and derivatives usage that are both hedging strategies do not have the same impact on French firms' value before and during the crisis.

\section{RoBUSTNESS TESTS}

We suspect an endogeneity problem in the equation 2 due to reverse causality between the exogenous variables end the dependent variables (LNTQ, ROA, and ROE). Foreign debt impacts firm performance and can be affected by the latter. To control for this potential problem, we employ an instrumental variables approach using a 2-stage least square regression (2SLS) similar to Bartram et al. (2009), Fauver and Naranjo (2010), and Allayannis et al. (2012).

We use a two-stage least squares estimation procedure to estimate the parameters in equation (2). In the first stage, separated OLS regressions are run for the performance, the foreign leverage (FOREIGN LEV) and the derivatives use (DERIV). In the second stage, structural equations are estimated by replacing the explanatory variables with the predicted values from the first-stage regressions. We exclude the Pre-crisis, Crisis, and Post-crisis variables in the first specification. In the second specification, we include the variables interacted with the predicted values of FOREIGN LEV and DERIV.
To estimate the predicted value of the use of foreign leverage, we regress FOREIGN LEV on instrumental variables along with other controls, as in equation (1). We use three variables as potential instruments: the percentage of firms in the same industry that use foreign debt, the amount of foreign debt to total assets by industry, and the percentage of sales in foreign currency. ${ }^{3}$

The predicted values of DERIV are estimated by regressing the variable DERIV on the instrumental variables and the other controls of equation (1). We use three instrumental variables: the percentage of firms in the same industry that use foreign currency derivatives, the mean value of the notional amount of foreign currency derivatives scaled by the total assets by industry, and the percentage of sales in foreign currency. ${ }^{4}$

To conserve space, we report only the second-stage estimation results of performance regressions in Table 6. These are consistent estimates of the second-stage results controlling for potential endogeneity and include all of the control variables in Table 5.

The results are very similar to those discussed in section 4.2 and reported in Table 4 . Only 3 differences exist. In the first specification with LNTQ as dependent variable, we notice that the coefficient of DOMESTIC LEV is not significant on the crisis period. Earlier, the coefficient of this variable was significant. In contrast to our earlier ROA results in Table 5, for the Post-crisis period, we now observe that the effect of derivatives usage is positive but remains non-significant. Finally, for the Pre-crisis period, the impact of foreign leverage is not significant. The results in Table 5 suggest that our conclusions are robust in controlling for endogeneity.

\section{Conclusion}

In this study, we examine the effect of foreign currency debt on firm performance for a sample of French firms over the period 2002 to 2012 . We address a question concerning the financial theories (capital structure and corporate hedging) that provide the best explanation of this effect. First, we examine how foreign currency debt impacts firm performance for three sub-periods: before, during, and after the 2008 crisis. Then, to answer our question, we compare the sign of the relation between the variables of performance (LNTQ, ROA and ROE) and foreign currency debt and domestic debt respectively.

We find evidence that foreign currency debt increases firm performance in the pre-crisis period and destroys it in the postcrisis period. During the crisis, foreign debt only enhances a firms' market value. In the pre-crisis period, the impact of foreign debt is consistent with predictions of the signaling theory and of the agency theory concerning the monitoring role of debt. This positive impact can also be explained by a corporate hedging logic. In the post-crisis period, the pecking order theory provides a valid explanation for the negative value-effect of foreign currency debt. The corporate hedging theory also suggests that foreign currency debt may not add value if it increases currency exposure and needs to be hedged with derivatives. This explanation is consistent with the negative impact of derivatives. During the crisis, arguments stemming from corporate hedging theory

3. To verify the instruments' validity, we perform several statistical tests (Sargan test and Hansen test) that test for the absence of correlation between the instruments and error term. The results are available under request.

4. The validity of the instruments was checked by Sargan test and Hansen test. 


\section{TABLE 6}

\section{Simultaneous equation analysis of firm performance and foreign debt}

This table reports results from a simultaneous equations two-stage estimating relating firm performance and foreign leverage. We simultaneously estimate separated OLS regressions for the performance, the foreign leverage (FOREIGN LEV) and the derivatives use (DERIV). We then use the predicted values of FOREIGN LEV and DERIV as explanatory variables in a second stage of the simultaneous equations system. This table reports the second-stage coefficients of firm performance on the predicted value of FOREIGN LEV and DERIV interacted with our period's dummies (Pre-cris, Crisis, Post-crisis). All the regressions contain the control variables similar to table $5 . a, b$, and $c$ indicate significance at the 1, 5, and 10\% levels, respectively.

\begin{tabular}{|c|c|c|c|}
\hline \multicolumn{4}{|l|}{ Second-stage results } \\
\hline Dependent variable & LNTQ & ROE & ROA \\
\hline DOMESTIC LEV $\times$ Pre-crisis & $\begin{array}{c}0.8800^{a} \\
(0.0000)\end{array}$ & $\begin{array}{c}-0.0071 \\
(0.7742) \\
\end{array}$ & $\begin{array}{c}-0.1123^{a} \\
(0.0000) \\
\end{array}$ \\
\hline DOMESTIC LEV $\times$ Crisis & $\begin{array}{l}-0.3121 \\
(0.3161) \\
\end{array}$ & $\begin{array}{c}-0.0658^{b} \\
(0.0111) \\
\end{array}$ & $\begin{array}{l}-0.0321^{b} \\
(0.0200) \\
\end{array}$ \\
\hline DOMESTIC LEV x Post-crisis & $\begin{array}{l}-0.289^{b} \\
(0.0158)\end{array}$ & $\begin{array}{l}-0.1888^{a} \\
(0.0080) \\
\end{array}$ & $\begin{array}{c}-0.1254^{a} \\
(0.0010) \\
\end{array}$ \\
\hline FOREIGN LEV $\times$ Pre-crisis & $\begin{array}{c}0.1222^{\mathrm{b}} \\
(0.0153) \\
\end{array}$ & $\begin{array}{l}0.0468^{\mathrm{b}} \\
(0.0201) \\
\end{array}$ & $\begin{array}{l}0.0201 \\
(0.211) \\
\end{array}$ \\
\hline FOREIGN LEV $\times$ Crisis & $\begin{array}{c}0.0299^{c} \\
(0.0872)\end{array}$ & $\begin{array}{l}-0.0126^{c} \\
(0.0602)\end{array}$ & $\begin{array}{c}-0.0123^{b} \\
(0.0454)\end{array}$ \\
\hline FOREIGN LEV x Post-crisis & $\begin{array}{l}-0.0223^{c} \\
(0.0733)\end{array}$ & $\begin{array}{l}-0.0301^{b} \\
(0.0352)\end{array}$ & $\begin{array}{l}-0.0062^{c} \\
(0.0523)\end{array}$ \\
\hline$D E R I V \times$ Pre-crisis & $\begin{array}{l}-0.3503^{b} \\
(0.0335)\end{array}$ & $\begin{array}{c}-0.0415 \\
(0.7528)\end{array}$ & $\begin{array}{c}-0.0101 \\
(0.8859)\end{array}$ \\
\hline DERIV $\times$ Crisis & $\begin{array}{c}-0.3028^{b} \\
(0.0275)\end{array}$ & $\begin{array}{c}-0.0963 \\
(0.2859) \\
\end{array}$ & $\begin{array}{c}-0.0384 \\
(0.3333) \\
\end{array}$ \\
\hline DERIV $\times$ Post-crisis & $\begin{array}{l}-0.4208 \\
(0.2302) \\
\end{array}$ & $\begin{array}{l}-0.0230 \\
(0.4251) \\
\end{array}$ & $\begin{array}{l}0.01026 \\
(0.2603) \\
\end{array}$ \\
\hline Other controls & YES & YES & YES \\
\hline No. observations & 1,269 & 1,269 & 1,265 \\
\hline Prob $>F$ & 0.0000 & 0.0000 & 0.0000 \\
\hline Adjusted R-squared & 0.3469 & 0.0891 & 0.1321 \\
\hline
\end{tabular}

explain the effect of foreign debt on French firms' performance. Foreign debt acts as a natural hedging strategy.

We do not have detailed information to distinguish foreign currency loans from foreign currency bonds. This may introduce a bias in our results. Indeed, the costs associated with these two types of debt are different. Moreover, French firms did not have the same access to bank loans and to market-based financing through debt depending on the period (before, during and after the crisis). Likewise, we do not know the debt's currency of denomination. This issue may be important if firms try to profit from lower interest rates. This suggests a need for further analysis because the impact of foreign currency debt on firm value can vary according to the type of debt (bank debt vs bonds) and the currency of denomination.

\section{References}

Aаво, T. (2006), "The Importance of Corporate Foreign Debt in Managing Exchange Rate Exposures in Non-Financial Companies", European Financial Management, Vol. 12, № 4, p. 633-649.

Allayannis, G., Brown, G.W., and Klapper, L.F. (2003), “Capital Structure and Financial Risk: Evidence from Foreign Debt Use in East Asia," Journal of Finance, Vol. 58, N6, pp. 2667-2710.

Allayannis, G. and Weston, J. (2001), "The Use of Foreign Currency Derivatives and Firm Market Value," Review of Financial Studies, Vol. 14, pp. 243-276.
Bartram, S., Brown, G.W., and Fehle, F.R. (2009), "International Evidence on Financial Derivatives Usage," Financial Management, Vol. 38, $\mathrm{N}^{\circ}$ 1, pp. 185-206.

Belghitar, Y., Clark, E., and Mefteh-Wali, S. (2013), "Foreign Currency Derivatives Use and Shareholder Value," International Review of Financial Analysis, Vol. 29, pp. 283-293.

Ben Khediri, K. (2010), "Do Investors Really Value Derivatives Use? Empirical Evidence from France,” Journal of Risk Finance, Vol. 11, January, pp. 62-74.

Ben Khediri, K., and Folus, D. (2010), "Does Hedging Increase Firm Value? Evidence from French Firms," Applied Economics Letters, Vol. 17, N¹0, pp. 995-998.

Bessembinder, H., (1991), "Forward Contracts and Firm Value: Investment Incentive and Contracting Effects," Journal of Financial and Quantitative Analysis, Vol. 26, pp. 519-532.

Bhattacharya, S. (1979), "Imperfect Information, Dividend Policy and the "Bird-in-Hand" fallacy". The Bell Journal of Economics, Vol. 10, pp. 259-270

Clark, E. and Judge, A. (2009), "Foreign Currency Derivatives versus Foreign Currency Debt and the Hedging Premium," European Financial Management, Vol. 15, №3, pp. 606-642.

Clark, E. and Mefteh, S. (2010). "Foreign Currency Derivatives Use, Firm Value and the Effect of the Exposure Profile: Evidence from France," International Journal of Business, Vol. 15, $\mathrm{N}^{\circ} 2$, pp. 183-196. 
CoAse, R. (1937), “The Nature of the Firm.” Economica, Vol. 16, $\mathrm{N}^{\circ} 4$, pp. 386-405.

Dunning, J. (1973), “The Determinants of International Product.” Oxford Economic Papers, Vol. $25 \mathrm{~N}^{\circ}$ 3, pp. 289-336.

Fauver, L. and Naranjo, A. (2010) "Derivative Usage and Firm Value: The Influence of Agency Costs and Monitoring Problems," Journal of Corporate Finance, Vol. 16, pp. 719-735.

Froot, K.A., Scharfstein, D.S., and Stein, J.C. (1993), "Risk Management: Coordinating Corporate Investment and Financing Policies," Journal Finance, Vol. 48, pp. 1629-1658.

Harvey, C.R. and Roper, A. (1999), “The Asian Bet," in: Harwood, A., Litan, R.E., and Pomerleano, M. (Eds.), The Crisis in Emerging Financial Markets. Brookings Institution Press, Washington, DC, pp. 29-115.

Hausman, J.A. (1978), "Specification Tests in Econometrics," Econometrica., Vol. 46, No. 6, 1251-1271.

Jensen, M. (1986), "Agency Costs of Free Cash-Flow, Corporate Finance and Takeovers," American Economic Review, Vol. 76, pp. 323-329.

Jin, Y. and Jorion, P. (2006). "Firm Value and Hedging: Evidence from U.S. Oil and Gas Producers," Journal of Finance, Vol. 61, $\mathrm{N}^{\circ}$ 2, pp. 893-919.

Keloharju, M. and Niskanen, M. (2001), "Why Do Firms Raise Foreign Currency Denominated Debt? Evidence from Finland," European Financial Management, Vol. 7, N4, pp. 481-496.

Lewellen, W.G. and Badrinath, S.G. (1997), "On the Measurement of Tobin's Q,” Journal of Financial Economics, Vol. 44, pp. 7-122.
Myers, S. and MaJULF, N. (1984), "Corporate financing and investment decisions when firms have information that investors do not have", Journal of Financial Economics, Vol. 13, N², pp. 187-221.

Mefteh-Wali, S. and Rigobert, M.J. (2013), "Les Facteurs Déterminants de l'Endettement en Devises des Entreprises Françaises," Finance Contrôle Stratégie, Vol. 16, N 4 , https:// fcs.revues.org/1395

Miller, M. (1977), “Debt and Taxes,” Journal of Finance, Vol. 32, pp. 261-276.

Modigliani, F. and Miller, M. (1958), “The Cost of Capital, Corporation Finance, and the Theory of Investment," American Economic Review, Vol. 48, pp. 261-297.

Mueller, D. (1987). The Corporation: Growth, Diversification and Mergers. Harwood, Chur, Switzerland.

Peltzman, S. (1977), "The Gains and Losses from Industrial Concentration," Journal of Law and Economics, Vol. 20, pp. 229-263.

Perfect, S. and Wiles, K. (1994), "Alternative Constructions of Tobin's Q: An Empirical Comparison,” Journal of Empirical Finance. Vol. 1, pp. 313-341.

Ross, S. (1977), “The Determination of Financial Structure: The Incentive Signaling Approach," Bell Journal of Economics, Vol. 8, pp. 23-40.

Smith, C.W. and Stulz, R.M. (1985), “The Determinants of Firms' Hedging Policies," Journal of Financial and Quantitative Analysis, Vol. 20, pp. 391-405.

Vivel, M., Otero, L., Fernandez, S., and Duran, P. (2013), "Is Value Creation Consistent with Currency Hedging?" European Journal of Finance, Vol. 21, № 10/11, pp. 912-945.

\section{APPENDIX}

This appendix presents the definition of variables used in the study.

Variables Definition

\begin{tabular}{|c|c|}
\hline ROA & $\frac{\text { Earnings before interest and tax }}{\text { Book value of total assets }}$ \\
\hline ROE & $\frac{\text { Net income }}{\text { Book value of total assets }}$ \\
\hline Tobin's Q & $\frac{\text { Book value of total assets - book value of equities - market value of equities }}{\text { Book value of total assets }}$ \\
\hline LNTQ & Ln(Tobin'sQ) \\
\hline FOREIGN LEV & $\frac{\text { Long-term foreigh currency debt }}{\text { Book value of total assets }}$ \\
\hline DOMESTIC LEV & $\frac{\text { Long-term local currency debt }}{\text { Book value of total assets }}$ \\
\hline SIZE & Ln(book value of total assets) \\
\hline DERIV & $\frac{\text { Fiscal year-end total national value of derivatives }}{\text { Book value of total assets }}$ \\
\hline CAPEX & $\frac{\text { Total of capital expenditures }}{\text { Book value of total assets }}$ \\
\hline QUICK & $\frac{\text { Total of available cash accounts and marketable securities }}{\text { Short-term liabilities }}$ \\
\hline DIV & $\frac{\text { Dividend per share }}{\text { Share price }}$ \\
\hline FSTS & $\frac{\text { Foreign sales }}{\text { Total sales }}$ \\
\hline PRE-CRISIS & Dummy variable equals 1 if the observation is for the years 2002 to 2006 , and 0 otherwise \\
\hline CRISIS & Dummy variable equals 1 if the observation is for the years 2007 to 2009 and 0 otherwise \\
\hline POST-CRISIS & Dummy variable equals 1 if the observation is for the years 2010 to 2012 and 0 otherwise \\
\hline
\end{tabular}

